\title{
Meta
}

Journal des traducteurs

Translators' Journal

\section{Translation Quality Assessment. Strategies, Parametres and Procedures}

\section{Jamal al-Qinai}

Volume 45, numéro 3, septembre 2000

La traduction dans le monde arabe

URI : https://id.erudit.org/iderudit/001878ar

DOI : https://doi.org/10.7202/001878ar

Aller au sommaire du numéro

Éditeur(s)

Les Presses de l'Université de Montréal

ISSN

0026-0452 (imprimé)

1492-1421 (numérique)

Découvrir la revue

Citer cet article

al-Qinai, J. (2000). Translation Quality Assessment. Strategies, Parametres and Procedures. Meta, 45(3), 497-519. https://doi.org/10.7202/001878ar
Résumé de l'article

L'évaluation de la qualité de la traduction a souvent fait les frais de jugements impressionnistes et souvent paradoxaux s'appuyant sur une esthétique bien vague. Cette étude cherche à construire un modèle empirique d'évaluation de la qualité qui s'appuie sur des paramètres objectifs de typologie textuelle, de correspondance formelle, de cohérence thématique, de cohésion référentielle, d'équivalence pragmatique et de propriétés lexicosyntactiques. La vérification de la viabilité de ce modèle éclectique passe par son application à l'analyse textuelle d'un texte évocateur (une publicité) avec pour but de faire ressortir les points convergents et divergents.
Ce document est protégé par la loi sur le droit d'auteur. L'utilisation des services d'Érudit (y compris la reproduction) est assujettie à sa politique d'utilisation que vous pouvez consulter en ligne.

https://apropos.erudit.org/fr/usagers/politique-dutilisation/ 


\title{
Translation Quality Assessment. Strategies, Parametres and Procedures
}

\author{
JAMAL AL-QINAI \\ English Department \\ Kuwait University \\ KU Research Grant AE027
}

\begin{abstract}
RÉSUMÉ
L'évaluation de la qualité de la traduction a souvent fait les frais de jugements impressionnistes et souvent paradoxaux s'appuyant sur une esthétique bien vague. Cette étude cherche à construire un modèle empirique d'évaluation de la qualité qui s'appuie sur des paramètres objectifs de typologie textuelle, de correspondance formelle, de cohérence thématique, de cohésion référentielle, d'équivalence pragmatique et de propriétés lexicosyntactiques. La vérification de la viabilité de ce modèle éclectique passe par son application à l'analyse textuelle d'un texte évocateur (une publicité) avec pour but de faire ressortir les points convergents et divergents.
\end{abstract}

\section{ABSTRACT}

Translation quality assessment has been marred by impressionistic and often paradoxical judgments based on elusive aesthetics. This study seeks to develop an empirical model for QA based on objective parametres of textual typology, formal correspondence, thematic coherence, reference cohesion, pragmatic equivalence and lexico-syntactic properties. This eclectic model is tested for its viability by applying it to the textual analysis of an evocative text (an advertisement) with the aim of highlighting points of correspondence and divergence.

\section{MOTS-CLÉS/KEYWORDS}

translation quality assessment, textual analysis, assessment parameters, assessment strategies, reception of source text

\section{Introduction}

\subsection{The Concept of Quality in Translation}

"A Translator is severely criticized if he makes a mistake, but only faintly praised when he succeeds" (Nida 1964: 155)

Readers often perceive the end-product of translation (i.e. target text) as the only material available for scrutiny. This tendency to ignore the process of decision making lies behind the lack of objectivity in translation assessment. Consequently, any attempt to evaluate translations by analytic comparison of source text (ST) and target text (TT) is bound to divert away from accuracy without considering the procedures undertaken by the translator to resolve problems (Hatim and Mason 1990: 3).

The ST writer selects lexical items and syntactic arrangement to suit his communicative aims. The translator works at recovering those aims. But this process is fraught with subjective interpretation of ST. After all, every reading of a text is unique in its own right and is bound to evoke different responses.

Over the last two decades, studies (House 1976; Wilss 1982; Basil and Hatim 
1990, Baker 1992 and Horton 1998) have ventured to introduce objectivity instead of subjective impressionism in judging translation quality. To this end, attempts have been made to develop an elaborate set of parametres, procedures and well-defined metalangue is needed in order to construct a pseudo-model for translation assessment. But this approach is not without its drawbacks. As House (1981:64) describes it, "it seems unlikely that translation quality assessment can ever be objectified in the manner of natural science." As there is neither a definitive reading of a text nor a perfect rendering which achieves the goals of ST, translation assessment and criticism could go forever.

Translation is a complex hermeneutic process in which intuition plays a crucial role in interpreting the intentions of the ST writer. Further, languages vary in their choice of lexical connotations, sentence structure and rhetorical strategies, the only tangible tools for assessment. It is prudent, therefore, to talk about the adequacy of a translation rather than the degree of equivalence. Quality is relative and absolutes of accuracy cease where the end user (i.e. client) imposes his own subjective preferences of style in TT. Standardization of quality is thus a fuzzy grey area. For instance, does accuracy and good translation mean that a shoddy poorly-written, poorly-structured ST be reproduced as a shoddy poor TT? Is it professional for a translator to act as a filter, an advocate of ST? Alternatively, should a translator produce a 'straight' translation rather than a 'sanitized' one? (ITI Conference 1994: 72-3).

\subsection{Assessment in Retrospect}

In the pre-linguistic era of translation studies, reference has often been made to such vague concepts as the spirit and flavour of ST as opposed to the natural flow of TT. This traditional paradox can best be summed up in the words of Cicero, "a translation should be free ... a translation should be literal" (House 1981: 2).

A step towards more objective criteria was initiated by Nida who propounded the "dynamic equivalence principle." According to Nida (1964: 159), the response of TT receptors should be similar to that of ST audience. But the question is whether this criterion can be tested empirically to produce objective quality statements; otherwise, it would remain "mentalistic and needs further definition." (Newmark 1974: 64)

Later studies by Nida and Taber (1969: 168-173) suggested the use of cloze tests (i.e. asking recipients to fill gaps of words deleted in TT) to measure the degree of comprehensibility and predictability without reference to ST. In other instances, recipients were given alternative TT versions for comparison. Yet, in the absence of ST and the lack of an objective yardstick for translation, quality is likely to be subject to impressions and personal background. This is particularly true of many TT readers who have no knowledge of metalanguage terms to use in describing their reaction.

Carrol (1966) measured the quality of a translation by the rate of informativeness and intelligibility. Yet, he was mainly concerned with scientific texts where style and figures of speech play a minimal role. Reiss (1971) called for determining function and type of source text before any quality assessment. But she stopped short form defining any objectively measurable norm to apply her approach.

In April 1994, a major conference, held in Nottingham U.K., debated the topic of 'Quality-Assessment, Management and Control.' The interest in the so-called BS5750 standard (equivalent to ISO 9002) which superseded BS 4755 emanated from the 
need to meet such issues as timely delivery, final presentation (layout, deadlines) hardware/software compatibility, customer liaison, satisfaction, feedback, billing rates, word counting and training (ITI Conference 1994). Regarding linguistic/textual compatibility of ST and TT, the standard provides general observations of common sense without any empirical standards for testing quality. For instance, clause 4.3 requires under "Contract Review" that clients should specify the objectives and readership for which the translation is intended. For example, a client may want a scientific article translated for publication in another country where style is paramount or to contest the grant of a patent in which case accuracy assumes priority over style (op. cit.: 32).

However, our interest in this study lies in textual/ functional (or pragmatic) compatibility (i.e. quality of linguistic conversion) rather than the logistics of management and presentation (i.e. quality of service). After all, the ultimate end-users are interested in the quality of the product and not the means sought to serve its creation.

\section{Setting-up A Model for Translation Quality Assessment (QA)}

The assessment of a translated text seeks to measure the degree of efficiency of the text with regard to the syntactic, semantic and pragmatic function of ST within the cultural frame and expressive potentials of both source language and target language. According to House's pragmatic-textual approach (1981: 28-9), translation operates not with sentences but with utterances. Equivalence, therefore, is sought at the pragmatic level even if it overrides semantic meaning. In other words, the primary interest of translation is units of discourse characterized by their use-value in communication. With this in mind, our purpose in this study is to develop an eclectic practical model that can be empirically tested for analyzing the linguistic and situational peculiarities of ST and TT in the pre-translational phase and the post translational assessment of TT quality. This eclectic model is put to the test by analyzing a selected text (an advertisement) in order to make objective statement about the relative match of ST and TT.

Among the parametres raised by Newmark (1988), Hatim and Mason (1990), Steiner (1994) and House (1981, 1997), we may highlight the following:

1. Textual Typology (province) and Tenor: i.e. the linguistic and narrative structure of ST and TT, textual function (e.g. didactic, informative, instructional, persuasive, evocative... etc.).

2. Formal Correspondence: Overall textual volume and arrangement, paragraph division, punctuation, reproduction of headings, quotation, motos, logos... etc.

3. Coherence of Thematic Structure: Degree of referential compatibility and thematic symmetry.

4. Cohesion: Reference (co-reference, proforms, anaphora, cataphora), substitution, ellipsis, deixis and conjunctions.

5. Text-Pragmatic (Dynamic) equivalence: degree of proximity of TT to the intended effect of ST (i.e. fulfillment or violation of reader expectations)and the illocutionary function of ST and TT.

6. Lexical Properties (register): jargon, idioms, loanwords, catch phrases, collocations, paraphrases, connotations and emotive aspects of lexical meaning.

7. Grammatical/ Syntactic Equivalence: word order, sentence structure, cleaving, number, gender and person (agreement), modality, tense and aspect. 
A Strict observance of such parametres remains illusory for wherever subjective discourse is involved, the interpretation of polyvalent words, culture-bound idioms and the subtle emphases of ST and TT are bound to differ. Yet, a TT which displays a high degree of explicit divergence from ST would normally be regarded as an autonomous or hermeneutic recreation of ST rather than a translation.

Unless motivated by linguistic or pragmatic variance, only minimal violations of the above parametres are permissible in translations which lend themselves to quality assessment. Yet, since no two languages are identical, either in meaning or in form, the best we can hope for is an approximation given the following variables:

a) Nature of ST message.

b) Purpose and intent of ST producer.

c) Type of audience.

In the following, we will test the validity of the parametres outlined above by applying them to an advertising text translated from English into Arabic. To facilitate the process of comparison and assessment, the ST and TT will be placed in direct juxtaposition.

\section{Textual Typology (Province) and Tenor}

Ogden and Richard (1946: 229) differentiate between two basic uses of language: the symbolic-referential and the emotive-expressive. In the symbolic use, the basic consideration is correctness of reference and lexical symbols. In the emotive/ vocative use, the attitude aroused in the addressee is of prime importance.

The text at hand (taken from Baker 1992: 71,80) belongs to the province of advertising. It is an Austin Rover brochure for the 1989 Metro Sport model. The two versions of the brochure were translated into Arabic during an in-service workshop for translators. The ST text is written to be read as if heard (i.e. performed in action). In such texts, one simply cannot produce all formal elements of ST. For example, rhythm, rhyme, assonance, alliteration, word puns, onomatopoeics and chiasmic order of words defy equivalent rendering.Alternatively, compensatory footnotes and marginal explanations often have a disruptive effect on the 'punch' or force of ST message.

The pseudo-dialogue and the consultative-casual style of ST is further developed through lax incomplete utterances, abbreviated forms and randomness of subject-matter. 'Normal non-fluency,' a feature of informal style, is evident in erratic punctuation, loosely co-ordinated sentences and non-finite constructions. At the lexical level, semi-colloquial expressions, phrasal verbs and simple informal (i.e. non-jargon) words are common.

Further, the advertising mode of the text manifests itself in the use of the evocative message which is aimed at persuasion. Despite the paraphrastic adaptations and calque translations of some technical jargon in the TT version, there's a high rate of convergence between ST and TT with regard to objective product information. The expressive-vocative (i.e. evaluative) aspect shows some manipulation in TT. This is largely due to the presence of ST idioms which have no direct TT equivalents and the somewhat informal style of ST as opposed to the high (written) variety of Arabic which is formal (see under lexical properties). 
The English text achieves a higher level of informality by using a casual chatty style without wrapping up the sentences as one would do in instructional leaflets. This is achieved by using second person pronoun to address the recipient directly in order to create a personal affiliation between addressor and addressee. In other words, the evocative style is brought into play to impart the feeling of product-exclusivity to the recipient. The appeal to ST recipient is enhanced by assuming that the recipient is already in possession of a Metro Sport car,

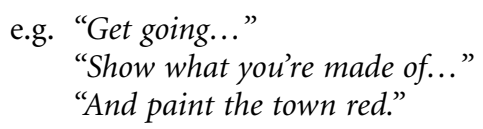

In contrast, Arabic has two varieties: a high written (formal) variety and a low spoken (mainly informal) variety. The classical (written) high variety lacks informal style and the result is that an informal ST style if often rendered as formal in TT. The translator's task is to reduce the gap by steering a middle course between the formal style of the high variety and the informal language of Colloquial Arabic (Aziz, "Style Shift": 31).

In the Metro Sport source text, the informal pseudo-dialogue pattern is altered in TT through the use of the high (written) variety of Arabic which requires full sentences, less idiomatic expressions and gender specification of the addressee. The latter (see under Coherence of Thematic Structure and Grammatical Equivalence) often leads to nominalization of potential TT verbal structures in order to avoid gender specification by grammatical agreement.

\section{Formal Correspondence}

The casual and informal pseudo dialogue of ST is deliberately intended to elicit addressee participation by creating an impression of immediacy and lack of premeditation, typical of the spoken mode. In other words, the ST is produced to sound impromptu, as if it were written spontaneously on the spur of the moment. This is manifest linguistically through the specific use of:

a) Incomplete sentences and loosely-structured clauses:

e.g. Your own sense of style is all your own. Brilliant. Colourful. Original.

Your new Metro Sport. Terrific looks. Loads of go. For a lot less than you think.

b) Particular theme/ rheme sequence: Some sentences retain a theme without a rheme

e.g. A new range.

The new metro sport.

or the theme is deleted while the rheme is preserved

e.g. With vivid new colours and trim.

And wickedly stylish.

(For more examples see under coherence of thematic structure).

c) Switches between interrogatives, exclamations and imperatives. The latter is particularly intended to give personal advice to the would-be purchaser. 
e.g. Get going in the new Metro GTa.

Where else would you find .... at such a price?

Or show what you're made of.

Right up your street?

(Relax - it's also remarkably economical).

Note that the use of parenthesis in the last example gives an air of one-to-one personalized chatting.

d) The text is predominantly etic (House 1981: 82). There is frequent reference to the addressee through the use of the deictic personal pronoun 'you, implying the addressee's immediate presence.

e.g. Your own sense of style is all your own.

You won't have to put up with a spartan...

e) The use of [+human] features for an inanimate object to personify the product.

e.g Sporty new models which ... don't hang around.

It's a lot more than just a pretty face.

- a hot little hatchback that knows how to handle itself.

f) The presence of informal figurative language and phrasal verbs instead of plain technical jargon. This creates a somewhat social intimate setting that makes the advertisement attractive and palatable to the addressee.

e.g. get up and go.

- and don't hang around.

... with a real sting in its tail.

Right up your street?

And paint the town red.

In contrast $\mathrm{TT}$ is less personalized and uses less evocative, figurative language. It is less geared to elicit addressee participation as the informational core is transmitted more straightforwardly at the expense of the interpersonal component. In other words, TT is more precise and sober than ST with regard to the ideational aspect. Accordingly, the intention of the ST producer to make his text attractive and easily digestible has not been fully realized in TT to the same degree as in ST in respect of the following:

a) Arabic seems to override sentence boundaries by substituting additive conjunctions for full stops.

Your own sense of style is all your own. Brilliant. Colourful. Original. With loads of get up and go.

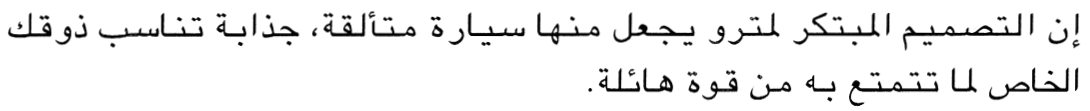

Now tune into the electronic stereo radio/ stereo cassette player. Four speakers, great sound. And a built-in security code theft deterrent.

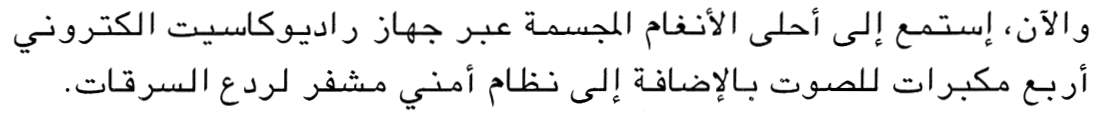


b) The addition of discourse connecting elements alter the thematic structure of the text and the line of argumentation. Thus, foregrounding (i.e. placing rheme before theme) in TT is limited compared to ST. From the above examples (under a) it is evident that the dramatic quality and emphatic effect of ST has been modified to a more neutral discourse.

c) Sentence Division and Punctuation: Arabic has no strict adherence to the Western idea of sentence division, subordination and punctuation. Generally speaking, TT exhibits less breaks than ST owing to the use of coordinating conjunctions such as كما 'and' كن 'but' كن 'further.'

Although this rechunking of text may be an idiosyncratic adjustment on the part of the Arabic translator, it can be linguistically justified on two main grounds:

a) The ST is divided into sentences that are too short in terms of TL norms

b) The idiosyncratic use in ST of sentence initial conjunctions such as 'And' and 'With' which tresspasses sentence boundary as marked visually by full stops. By this means, the English text achieves a higher level of informality, as if the writer is taking issues casually as they occur to him/ her. The use of '- and don't hang around' and 'Or show what you're made of..." gives the impression that the writer is thinking aloud in a chatty style rather than firmly wrapping up the text (Baker 1992: 200-201).

The use of explicit conjunctions in TT to substitute punctuation marks in ST makes the structure of the text more transparent. For instance, the 'reason' for the Metro being classified as a sports car is made more explicit in Arabic by adding in the sentence

$$
\text { فهي سيارة هـاتشبـاك حديثة و مدمجـة ... }
$$

The delight of Arabic in the flowery elegance of well-connected and constructed sentences results in a modified rhetorical development of the text as the information contained in one sentence is consolidated in another. The change in sentence division is quite visible in the overall number of sentences in both ST and TT.

Figure 1: Overall no. of Sentences in ST and TT.

\begin{tabular}{|c|c|c|c|}
\hline \multicolumn{2}{|c|}{ ST I } & \multicolumn{2}{c|}{ TT I } \\
\hline Paragraph No. & No. of Sentences & Paragraph No. & No. of Sentences \\
\hline 1 & 5 & 1 & 1 \\
\hline 2 & 8 & 2 & 4 \\
\hline 3 & 2 & 3 & 2 \\
\hline 4 & 3 & 4 & 1 \\
\hline 5 & 3 & 5 & 2 \\
\hline Total & 21 & Total & 10 \\
\hline
\end{tabular}




\begin{tabular}{|c|c|c|c|}
\hline \multicolumn{2}{|c|}{ ST II } & \multicolumn{2}{c|}{ TT II } \\
\hline Paragraph No. & No. of Sentences & Paragraph No. & No. of Sentences \\
\hline 1 & 4 & 1 & 2 \\
\hline 2 & 2 with 2 semi-colons & 2 & 4 \\
\hline 3 & 2 & 3 & 1 \\
\hline 4 & 2 & 4 & 2 \\
\hline 5 & 3 & 5 & 1 \\
\hline 6 & 1 & 6 & 2 \\
\hline 7 & 3 & 7 & 13 \\
\hline Total & 17 with 2 semi-colons & Total & 1 \\
\hline
\end{tabular}

\section{Coherence of Thematic Structure:}

Both ST and TT exhibit a broad consistency in thematic development. The narrative exposition introduces the car by describing its impressive body design while creating a parallel with its hidden features that render it worthy in both looks and performance. This description is intersected with a series of quality statements, each tackling the product on the antithesis of adventure $v s$ reality and stylish design $v s$ economy.

The choice of a given theme/ rheme sequence in a sentence indicates the ST point of departure. Some choices are meaningful because they are more marked than others. According to House (1981: 55), in normal unmarked speech, the theme precedes the rheme (objective position) while in emotive speech the rheme precedes the theme. Foregrounding (i.e. fronting rheme to sentence initial position) is a rhetorical device for highlighting a particular linguistic form through attracting attention to it.

In the Metro Sport advertisement, some sentences seem to be awkward with regard to theme/ rheme configuration. For example, some ST sentences have only a theme that stands on its own in vaccum while the text is intersected with full stops placed prematurely.

e.g The New 1989 Metro.

A new range.

The new Metro Sport.

Similarly, other clauses and adverbials which could well serve as rhemes are detached from their themes by full stops and introduced by conjunctions or prepositions with anaphoric reference to themes in earlier sentences. Here, ellipsis, a hallmark of ST, is omnipresent. Various clause elements (e.g. subjects in themes, auxiliaries and verbs in rhemes) are deleted while punctuational marks (full stops, semicolons) are inserted in unexpected places. This tactic of deliberately stripping the message of its primary constituents is intended to signal marked elements as complete units of information.

e.g. Brilliant. Colourful. Original.

With vivid new colours and trim:

For a lot less than you think.

And a built-in security code theft deterrent. 
The theme in these examples is omitted because:

1. It is predictable and recoverable from previous sentences.

2. The ST writer intends to highlight the features and accessories of Metro Sport by foregrounding the rheme.

In other instances, foregrounding may take the form of semi-cleft sentences wherein a subordinate clause is fronted.

e.g. With a sunroof, central locking .... the new Metro is just the ticket.

Under the bonnet is a 73 ps 1.3 engine.

In the first sentence, foregrounding is intended to highlight Metro features, while in the second the 'powerful' engine is introduced with the adverbial in order to create an air of dramatic suspense. Otherwise, the expression 'under the bonnet' is redundant, for where else can an engine be? Unless, of course, 'the bonnet' is used as a metonym for the car.

This flash-card style of discourse organization and thematic structure gives the impression that the ST was originally written to be enacted with all the audio (or even visual) effects of pause, intonation, stress, various pitch contours ... etc.

The emerging theme/ rheme pattern of ST can be described as 'theme bouncing.' The ST producer establishes a hypertheme (i.e. Metro Sport) in a given sentence and strips the following sentences of their themes, which if reinstated are more or less a reiteration (verbatim or pronominal) of the hypertheme. The following is a rough sketch of ST theme/ rheme organization.

Figure 2: Theme Bouncing Technique in ST

$\begin{array}{lccc}\text { Hypertheme } & \mathrm{T} 1 \rightarrow & \mathrm{R} 1 \\ & & \downarrow \\ & \mathrm{T} 2=\varnothing & \mathrm{R} 2 \\ & & \downarrow \\ & \mathrm{T} 3=\varnothing & \mathrm{R} 3 \\ & & \downarrow \\ & \mathrm{T} 4=\varnothing & \mathrm{R} 4 \\ \text { (Reiteration of } \mathrm{T} 1) & \mathrm{T} 5 \stackrel{\mathrm{R} 5}{\rightarrow} & \\ & \mathrm{T} 6=\varnothing & \mathrm{R} 6 \\ & \mathrm{~T} 7=\varnothing & \mathrm{R} 7 \\ & & \\ & \mathrm{~T} 8=\varnothing & \mathrm{R} 8 \\ & \mathrm{~T} 9 & \mathrm{R} 9\end{array}$

Yet, TT seems to violate this pattern. The Arabic translation tends to conflate theme with rheme and fill in the missing (linking) reference by adding conjunctions and/ or pronouns to override punctuation marks.

e.g. The Sport looks just what it is - a hot little hatchback that knows how to handle itself. With an aerodynamic tail spoiler; all while sports wheel trims.

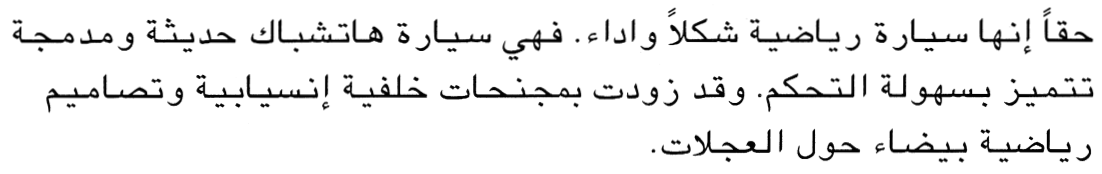


Sporty new models which look great - and don't hang around.

وهي متوفرة بموديلات رياضية جميلة الشكل عظيمـة الأداء.

Likewise, reference to hypertheme is reinstated in TT through pronominal agreement in the form of affixes attached to some rheme constituents.

e.g. Get going in the new Metro GTa. Where else would you find 73PS performance, alloy wheels and looks like that-at such a price?

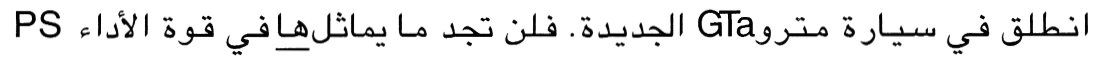

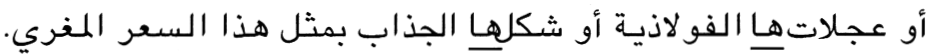

Another aspect in which TT deviates from ST is the verb form. Since Arabic verbs are inflected for person, gender and number (in predicate position) both theme and rheme are often combined in the form of an inflected verb which is affixed with pronoun (i.e. theme) markers. Consequently, the Arabic verb would carry the same information as an English pronoun-plus-verb combination (Baker 1992: 127).

e.g. Your own sense of style is all your own. Brilliant. Colourful. Original. With loads of get up and go.

كارة متألقة وجذابـة تناسب ذوقك

Full of fresh ideas.

Frequently, Arabic verbs occur in thematic position and the fronting of a predicator (i.e. rheme foregrounding) in ST is, therefore, not marked. The impact of reorganizing the ST theme/rheme pattern into verb-initial sentence - typical of Arabic - would change the focus of the message and may require a repetition of the theme proper (or a pronominal) to reestablish reference. For instance, in the nominal structure of ST

The new Metro Sport. Terrific looks....

is rendered as a verbal sentence in TT with the theme 'Metro Sport' pushed further away from its position.

$$
\text { تتميز سيارة مترو سبورت الجديدة بشكلها الرائع. }
$$

Aside from consolidating theme with rheme, the verb تتميز reveals the rheme prematurely and exhibits inflectional agreement with theme.

Similarly, in a sentence like

With a sunroof, central locking ..., the new Metro 1.3GS is just the ticket.

The Arabic particle ${ }^{\prime}$ and the verb (with inflectional agreemet) are placed in a frontal predicate immediately before the theme 'Metro 1.3Gs' while the rhematic complement in ST is shifted from initial position to sentence-end position, thus neutralizing the dramatic effect of suspense created by foregrounding.

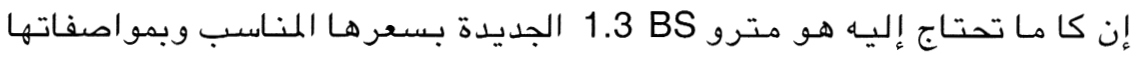

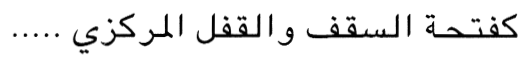


A translator from English into Arabic should try to use other means to convey the markedness attached to an English fronted predicator. S/he may, for instance, insert an independent pronoun in theme position for emphasis although a series of pronouns in sentence initial positions will be atypical of Arabic. Other alternatives

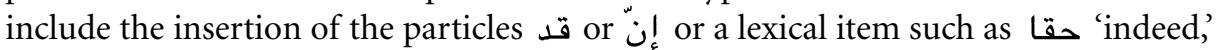
'in fact' or في الواقع 'actually' to preserve the prominence given by the ST writer to the fronted element (Baker 1992: 128, 135, 139).

e.g. Sport new models which look great ...

وهي متوفرة بموديـلات ريـاضيـة جميلة (initial pronoun)

For a lot less than you think.

كل ذلك بسعر أقل مما تتصور . Lexical item كل

With an aerodynamic tail spoiler...

(قد particle وقد زودت بمجنحات خلفيـة ....

\section{Cohesion:}

The concept of good rhetoric varies from culture to culture. Thus a given TT rendition might be considered out of focus when a translator merely copies ST rhetoric and sequence of thought which is alien to TL recipients.

Compared to Arabic, English generally prefers to present information in relatively small chunks using a wide variety of conjunctions and a highly developed punctuation system to signal breaks in sentences. Unlike English, Arabic prefers to group information in large chunks within relatively complex (usually long) sentences. This is partly because punctuation and paragraphing are a recent development in Arabic. Alternatively, Arabic tends to use a relatively small number of conjunctions whose exact meaning depends on reader's interpretation of the context. Thus the conjunctions هiا / و / ف / كما / are used not as precise logical connectives but only to indicate that one sentence is linked with another without reference to the semantic nature of the connection be it additive, temporal, causal or continuative.

e.g. Sporty new models which look great .... A new range.

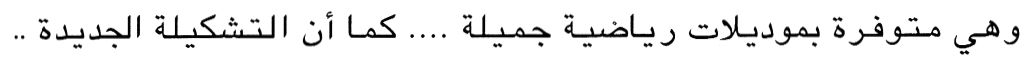

This, of course, contrasts with the intentional use of marked, sentence-initial conjunctions in ST. For example, ST uses 'And' at the beginning of sentences such as

And wickedly stylish.

And a performance engine that...

And so is the price.

And a built-in security code

And paint the town red.

By contrast TT does not consider sentence-initial 'And' as marked since the equivalent conjunction $g$ is unmarked in Arabic. There is hardly any sentence that does not begin with $g$ or a similar conjunction. Further, the initial 'And' in ST is rendered as a sentence medial conjunction in TT since short sentences are combined in longer more complex ones. 
e.g. There's a car after your own heart. The new 1989 Metro. Sporty new models which look great - and don't hang around. A new range. With vivid new colours and trim. Full of fresh ideas. Luxurious. And wickedly stylish.

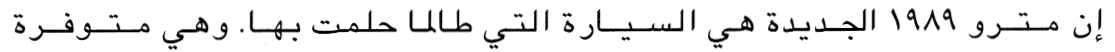

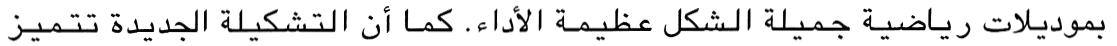

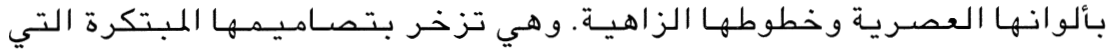
تجمع مـا بـين الرفـاهيـة والأناقـة المذهلة.

In like manner, ST uses 'with' in sentence-initial position which is also a marked conjunction used in a peculiar way in this text. Once again, TT renders 'with' in an unmarked equivalent $\varphi$ (or its equivalent) as a medial sentence conjunction.

e.g. With loads of get up and go.

لما / بما تتمتع بـه مـن قوة هـائلة

With vivid new colours...

تتميز بألوانها العصريـة

With a sunroof...

وبمواصفاتها كفتحسة السقفـ...

With an aerodynamic tail spoiler.

وقد زودت بمجنحـات خلفيـة إنسيـابيـة

Finally, cohesion in ST is further established by pronominals mostly with anaphoric reference. In this regard, Arabic employs more pronouns affixed to verbs, adjectives and nominals as markers of grammatical agreement.

It's got style. المتميزة بتصسميمهـا

It's a lot more than just a pretty face. يجعلها جليرة بـاســها شكلاً و أداء

Just what it is... إنها رياضيـة شكلاً و أداء

The following is a breakdown of type and frequency of cohesion elements in both ST and TT.

Figure 3: Type and Frequency of Cohesive Devices in ST \& TT.

\begin{tabular}{|c|c|c|}
\hline Type of Cohesive Device & \multicolumn{2}{|c|}{ Frequency } \\
\hline & ST & TT \\
\hline and 9 & 9 & 20 \\
\hline With $\longrightarrow$ or its equivalent & 6 & 2 \\
\hline or $\mathbf{l}$ & 1 & $34^{*}$ \\
\hline pronoun & 18 & \\
\hline
\end{tabular}

${ }^{*}$ Excluding grammatical agreement affixes.

The above data demonstrate that TT employs more explicit cohesive devices to overcome the somewhat lax system of punctuation in Arabic. 


\section{Text-Pragmatic (Dynamic) Equivalence:}

The terms used for the degree of equivalence vary from 'functional equivalence' to 'equality of textual effect,' 'closest natural effect,' 'stylistic equivalence,' to 'formal $v s$ dynamic 'equivalence,' and 'text-pragmatic equivalence' (Wilss 1982: 135). The textpragmatic approach is particularly promising; it is based on the assumption that the translator must use specific transfer strategies applicable to text genre and the sociocultural orientation of TT recipients. That is, the quality of TLT is not judged by mere vague and impressionistic terms but rather on our knowledge of reality and actual or predicted reader feedback. In order to build up this background knowledge a translator/ critic should perform the following pre-translational tasks:

a) A translator first traces the intention and objective of ST producer. The choice of such matters as structure and texture of ST including ellipsis, additions and stylistic peculiarities (or idiosyncrasies) can only be interpreted in relation to ST intended meaning (Hatim and Mason 1990: 12). In many cases, however, the translation critic is normally unaware of the considerations that have guided the translator in his work, unless they have been stated explicitly (Wilss 1982: 220).

In the Metro-Sport advertisement, the intentions of the ST producer are identical with the translator's: to sell the product by persuation and appeal to the prospective client's desire to own an elegant (visual appeal) but reliable (performance) car at a competitive price. Such intentions are made relatively transparent through the textual genre (a commercial advertisement) and the dramatic pseudo-dialogue format which is intended to impress the recipient by means of an informal highly-idiomatic style.

b) The success or failure of the translator in relaying the intentions of the ST producer are measured against the ST and TT corresponding genre and the sociocultural context of ST production and TT readerships. For instance, in the Metro-Sport text where properties of form (idioms, informal expressions, puns, imagery, peculiar punctuation, rheme foregrounding, ellipsis ... etc.) are of paramount semiotic value, only creative transposition is possible. Nevertheless, the formal nature of TT standard Arabic, the reinstatement of ST ellipted themes and the insertion of conjunctions to produce longer, more complex sentences (thus overriding peculiarities of punctuation) and finally paraphrasing ST idioms have all contributed negatively towards making TT more directive than persuasive.

Since the evocative aspect of a given ST can rarely be replicated in other languages, total recreation of ST is impossible. Translators/ critics will always suffer from a conflict of communicative priorities: which comes first message or form? This daunting question cannot be resolved unless the translator sets his objectives on how to approach the text: is it author-centered, text-centered or reader-centered? If, for example, as with the text at hand, the ST writer attempts to appeal to or evoke the reader, the effective function is likely to dominate the informative function. This persuasive/excitatory function can be crudely assessed by its practical effect: did the reader buy the product? (Newmark 1982: 133).

Even if a text is cohesive and coherent, the producer/ sender of ST must intend it to contribute towards some goal (giving/ demanding information/goods ... etc.) 
which has to be accepted by the recipient in order to achieve efficient communication (Bell 1991: 167). Unfortunately, the sender's intentions and receiver's interpretation of that intention may fail to coincide.

From a pragmatic perspective, a translator/ critic should consider the communicative force of an SL utterance which goes far beyond the propositional meaning of ST. To use pragmatic jargon, the illocutionary act of ST is realized through a number of speech acts:

5.1. Verdictives: acts which evaluate and relay judgment.

e.g. Sporty new models which look great - and don't hang around.

وهي متوفرة بموديلات ريـاضيـة جميلة الشكل عظيمـة الأداء.

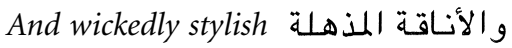

- a hot little hatchback that knows how to handle itself.

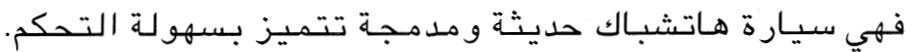

The TT manages to preserve ST verdictives though in a different form. The informal ST idiomatic expression 'don't hang around' is paraphrased into a formal post-

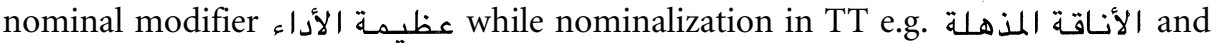
replaces ST adverbial and verbal structures.

5.2. Directives: Acts which seek to influence text recipients (e.g. ordering, requesting, daring).

e.g. Where else would you find 73PS performance...?

نلن تجد مـا يماثلها في قوة الأذاء.

Right up your street?

أليس هذا مـا تصبيوا إليـه

Or show what you're made of ... اطلق العنـان لرغباتك.

The first two ST rhetorical questions are aimed at soliciting the addressee's participation through dramatic force. Yet in TT the first question is rendered more as a verdictive statement while the second question is made formal, thus losing some of its appeal for affinity and reciprocity.

Other examples would include occasions where the writer anticipates and resolves problems for the reader.

e.g. Relax - it's also remarkably economical

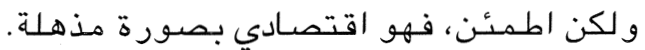

In this example, the imperative form is preserved though in a formal style. However, from a socio-cultural perspective, the word اقتصـادي 'economical' is not of primary concern to most Arabic speakers where fuel economy is not an issue.

5.3. Commissives: Acts which commit the speaker to a course of action (e.g. promising, vowing, pledging, ... etc.). 
There's a car after your own heart. The new 1989 Metro.

إن مترو 1919 الجديدة هي السيارة التي طالما حلمت بها.

Metro 1.3GS is just the ticket.

إن كل مـا تحتاج إليـه هو مترو

Aside from paraphrasing ST idioms and the informal style, TT retains the illocutionary force of ST commissives.

\section{Lexical Properties (Register)}

It is quite common to see idioms in English advertisements and promotional material. Yet, the formal written mode of TT (i.e. Arabic) which tends to avoid using idioms, contrasts with the highly informal idiomatic nature of ST. This style shift can be realized in the following TT renditions of ST idioms.

Figure 4: TT Formal Rendition of ST Idioms.

\begin{tabular}{|c|c|}
\hline ST & $\mathrm{TT}$ \\
\hline With loads of get up and go & لما تتمتحع بـه مـن قوة هـائلة \\
\hline show what you're made of & أطلق العنـان لرغبـاتك \\
\hline with a real sting in its tail & محركها الجبار \\
\hline Right up your street & أليس هذا مـا تصبو إليـه \\
\hline And paint the town red & و انطلق إلى عالم المر ح الصساخب \\
\hline
\end{tabular}

Generally speaking, determining which form is suitable for translating SL idioms depends on register, rhetorical effect and cultural norms. In other words, an accurate TT idiom may not necessarily be the most suitable for the purposes of the immediate text at hand. The following is a classification of TT strategies in dealing with ST idioms (adopted from Baker 1992: 71-78):

6.1. Idioms of similar meaning and form: This is probably the ideal (though rarely implemented) strategy, provided that the image has comparable frequency and currency in the appropriate register.

e.g. Get going إنطلق (although more formal than ST)

Full of fresh ideas تزخر بتصاميمها المبتكرة (although more formal than TT).

\subsection{Idioms of similar meaning but dissimilar form (substitution):}

e.g. after your own heart $\rightarrow$ التي طالسا حلمت بها

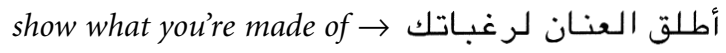

although Arabic has a less formal idiom of similar meaning and form:

$$
\begin{aligned}
& \text { لنرى معدنك و أنت تقود .... }
\end{aligned}
$$

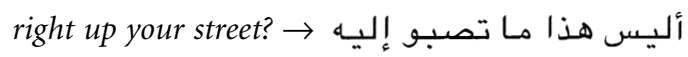

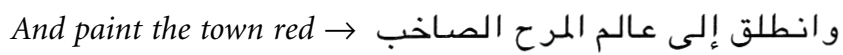


In the examples above, the translator replaces ST images with TT images which do not coincide with ST either in form or formality.

6.3. Translation by paraphrase: paraphrasing is prompted by the lack or inappropriateness of TT equivalent idioms for stylistic reasons. This, however, negatively affects the force or 'punch' of the message intended by the ST as it transfers the sense rather than the image.

e.g. With loads of get up and go. $\rightarrow$ لـتمتع بـه مـن قوة هـائلة

and don't hang around $\rightarrow$ عظيمـة الأد فاء

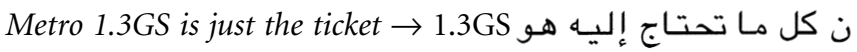

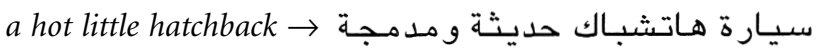

with a real sting in its tail $\rightarrow$ (محركها) الجبار مد

Another source of lexical disparity between ST and TT is that words with strong connotations in the original may have only denotative equivalents with neutral connotations in TT. For example, 'hot' does not only mean حديثة but also implies 'stylish'

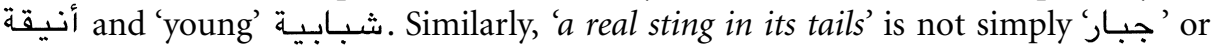
' ذو قوة هـائلة'، 'but it indicates that the car is 'rear-wheel drive' thing which is missing in TT. 'And paint the town red' has been idiomatically rendered in TT as انطلق إلى عالم المرح but it has lost the connotations of 'red' as the traditional colour of trendy sports cars.

The use of intensifiers and emphatics in ST has either been reduced or modified in TT

e.g. Your own sense of style is all your own.

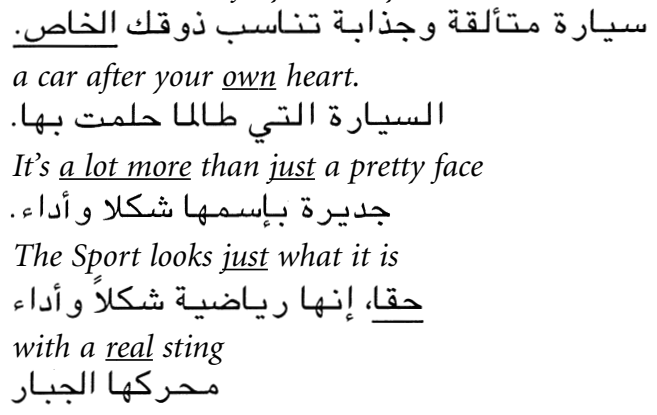

Lust by those stylishly trimmed sport seats for size.

ما عليك سـوى أن تنـم نفسك بالمقاعد المثيرة ذات الزخارف

all-white sports wheel trims

تصامييم رياضيـة بيضاء حول العجلات

Repetition of certain lexical items plays a role in maintaining the constancy and consistency of the message. The adjective 'new', for example, is repeated eight times in the ST with only five times in TT owing to the use of longer sentences, which makes a repetition of the adjective 'new' somewhat superfluous. 'Sport,' on the other hand, is used nine times in ST both as a proper model name and a common adjective whereas in the Arabic TT it has been transliterated four times only as a model name .رياضيـ and four times as a translated adjective سبورت 
Finally, auto jargon is either paraphrased or adopted as transliterated loanwords. To begin with, the product and model names are retained as in ST to preserve the exotic appeal of the English foreign name.The same can be said of 73PSI.3, 1.3GS, hatchback, tachometer ... etc. which give a better impression of high tech features than when rendered in direct (paraphrased) TT equivalents.

Figure 5: TT Rendition of ST Jargon

\begin{tabular}{|c|c|}
\hline ST & $\mathrm{TT}$ \\
\hline Metro-Sport & متروسبورت \\
\hline Metro GTa & GTa مترو GT G \\
\hline 73PS performance & قوة الأداء (73PS) \\
\hline Metro 1.3GS & 1.3GS مترو \\
\hline hatchback & هـاتشبـاك \\
\hline aerodynamic & إنسيابي (إيرودينامي) \\
\hline tail spoiler & مـنــات خلفيـة \\
\hline $\begin{array}{l}\text { electronic stereo radio/ } \\
\text { stereo cassette } \text { player }^{*}\end{array}$ & 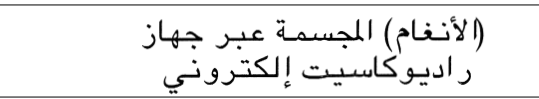 \\
\hline built-in & $\begin{array}{l}\text { ellipted, though مبيّت is a possible } \\
\text { but unpopular equivalent }\end{array}$ \\
\hline tachometer & مقيـاس لسرعة دور ان المحرك tachometer \\
\hline
\end{tabular}

* notice that "player" has been ellipted owing to the presence of an unacceptable TT equivalent 'recorder not player.'

\section{Syntactic Equivalence}

7.1. Word Order and Sentence Structure: Since word order is relatively fixed in English, the meaning of a given sentence depends on the order of its constituents. Compared to English, Arabic has a more flexible and versatile word order since case inflections determine functional elements such as subject, predicator, object ... etc. Coupled with grammatical agreement (for gender/ number/ person) which helps in establishing reference, such features enabled TT to compress short ST (including single-word) sentences into relatively longer and more complex sentences by means of conjunctions.

e.g.

Your own sense of style is all your own. Brilliant. Colourful. Original. With loads of get up and go.

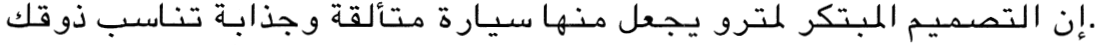

$$
\begin{aligned}
& \text { الخاص لما تتمتع عـه من قوة هـائلة. }
\end{aligned}
$$

As we explained earlier under 'Formal Correspondence' and 'Cohesion,' this syntactic change has resulted in a rhetorical shift. The use of single word sentences is intended to pound the features of the car as prominent in their own right. Glossing over sentence boundaries has nullified this effect on TT readers. 
Other syntactic modifications include constituent rearrangements. For instance, in the existential sentence,

There is a car after your heart,

the word 'there' and the indefinite 'notional' subject 'a car' have been replaced in TT by the following (single theme) sentence,

The new 1989 Metro.

to be rendered as إن مترو 1919 هي السيارة التي طالما حلمت بها which, once again, has nullified the effect of dramatic suspense created by delaying the product's name. The same can be said of the sentence,

With a sun roof, central locking ... Metro 1.3GS is just the ticket.

إن كل مـا تحتاج إليـ هو مترو 11.3GS الجديدة بسعر ها المناسب وبمو اصفاتها .......

Apart from a sentence such as

تتميز سيارة مترو سبورت الجديدة بشكلها الرائع ...

which uses an Arabic VSO order instead of the usual English SVO pattern, the TT translator managed to use equivalent nominal structures in Arabic by introducing هي or the pronoun

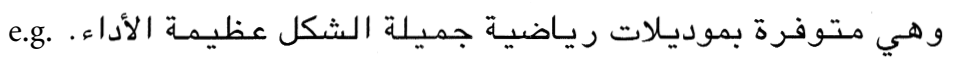

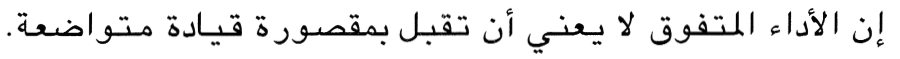

\subsection{Pronouns and Grammatical Agreement:}

The Metro Sport advertisement assumes a pseudo-dialogue by means of direct address of the recipient (i.e. second person singular) in order to involve the addressee and heighten his interest. The pronouns 'you' and 'your' are indiscriminately used in English regardless of number and gender. For example, in 'For a lot less than you think, there is no marker to specify number (singular/ dual/ plural) or even gender. The translator has, therefore, to make a choice from one of the following options:

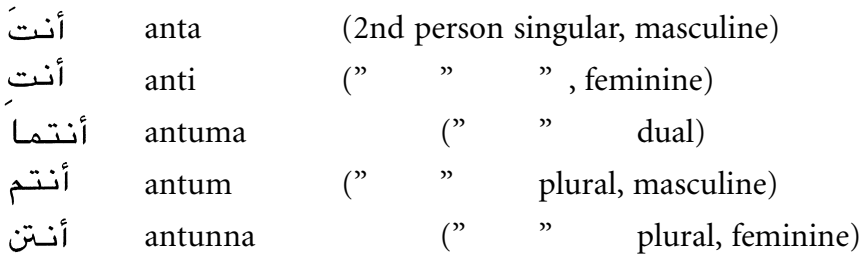

The problem is compounded with the fact that determiners, adjectives and verbs in Arabic agree with nouns and pronouns in number as well as in gender. Given the informal nature of ST, the second person dual and plural pronouns are excluded in favour of the singular. yet, the translator still has to make a decision between the masculine and feminine pronouns and the gender agreements entailed thereof. But as the sex of the referent in the ST is not known, the unmarked masculine rather than the feminine form is used. In other words, the use of the 'dominant' masculine form does not rule out the possibility of feminine reference. Therefore, the TT translator opted for a masculine pronoun throughout the text. 
e.g.

$$
\begin{aligned}
& \text { كل ذلك بسعر أقل مماتنصور بكثير. }
\end{aligned}
$$

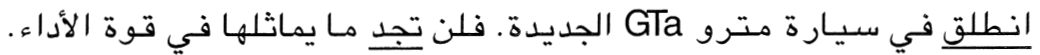

A translator into Arabic may find this approach too simplistic to be applied in the case of an advertisement where the evocative effect is most prominent. The use of the masculine in the absence of a neutral pronoun in Arabic may result in sacrificing the readability of the text and the loss of potential clientele owing to the failure of TT in marketing the product to the female sector.

Since this pronominal shift in gender cannot be resolved by a neutral pronoun, a translator can adopt one of the following strategies:

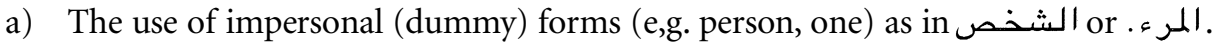

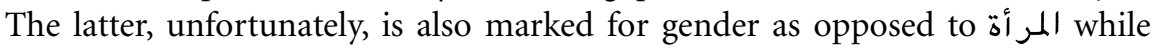
may distance the addressee owing to the loss the direct second person pronoun.

b) The use of the passive voice: In this evocative text, the use of the passive may change the focus of the message by isolating the recipient and render most imperative (directive) verbs untranslatable.

e.g. Get going in the new Metro GTa.

Show what you're made of...

Now tune into the electronic....

c) The use of the second person pronoun without the inflectional suffix (i.e. the diacritic) that indicates gender: yet, this may not solve the problem of verb or adjective agreement which can be in the form of a prefix, infix or ablaut. In fact, Arabic pronouns are often coded in the inflection of the verb, thus making an explicit mention of the pronoun redundant.

e.g. Fancy something really special ... هل تبحث عن سيارة متميزة حقيا

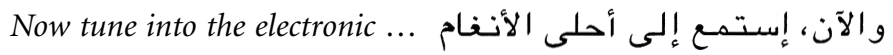

d) The use of the dual pronoun to appeal to both sexes: this has its own shortcoming since it may be restricted to couples and is likely to change the image of the car from a sports model to a family station-wagon!

e) The use of the second person plural pronoun أنتن or أنتم which, unfortunately, is marked for gender. Besides, the use of such a plural pronoun might endanger the informality of the advertisement since there is no air of reverence or deference shown towards the recipient in the ST. After all, the car is a sports model and the best way to establish affinity with young customers is through informal address. Otherwise, the tenor of discourse and overall effect of ST will be negatively affected.

With the failure of the above strategies, the loss of gender neutrality as a result of using the masculine second person singular أنت as a dominant pronoun becomes inevitable. 


\section{Final Assessment: a Holistic View}

If (QA) is to overcome the state of instability, it must build up a taxonomy of translational-critical criteria guaranteeing a systematic and objective evaluation of TT. (Wilss 1982: 222)

Instead of passing sweeping value-judgments on the overall quality of TT, it would be more sensible to screen the points of equivalence and the points of divergence at various levels of analysis in line with the model we've proposed in this study.

So far, we have been attempting to replace the predominantly intuitive judgment of translation quality by explicit, textually-based assessment of TT. Generally speaking, the Arabic version seems to be capable of reconstituting the message of ST by recreating its own coherence, thematic development and compensating for losses at the rhetorical/ lexical and formal levels.

Apart from the overall correspondence between ST and TT, there are various points of divergence and adaptation. These include the following:

1. Tenor: The informal casual style of ST has been made formal in TT.

2. Coherence and Formal Correspondence: Arabic overrides ST sentence boundaries by substituting additive conjunctions for stops and retrieving ST ellipted constituents (theme or rheme). This has altered the dramatic effect of ST 'flashcard' sentences, hyperthemes and foregrounded rhemes.

3. Cohesion: the infusion of additional cohesive links has made TT more explicitly informative and less casual.

4. Text-pragmatic (Dynamic) Equivalence: The formal style of TT, the reinstatement of ellipted items and the use of longer and more cohesive sentences have all contributed negatively towards making TT more directive than persuasive.

5. Lexical Properties: The highly-idiomatic ST expressions have been downtoned in TT. The parallel or paraphrastic TT renditions may not have affected the denotative aspect but they certainly influenced the connotations of idiomatic expressions.

6. Syntactic Equivalence: the use of the second person masculine pronoun in TT and the ensuing grammatical agreement for number and gender are in clear non-isomorphic syntactic correspondence to ST.

\section{Conclusion}

The role of TT is not simply to recast ST in another language, but to function as an effective medium (of advertising) in the TL environment. In other words, ST is viewed as an informational core and is therefore manipulated to achieve maximum effectiveness in the TL version within the cultural norms of the recipient language (Horton 1998: 108).

Among the strategies used to assess the degree of amendment and adaptation is back translation of TT into SL. Although this process is fraught with problems such as the influence of the translator's level of competence, selectional decisions and mis/ interpretation of SL, it may offer a rough picture of the multi-faceted transfer process. Nida (1964: 154-5) believes that no translator can avoid a certain degree of personal involvement in his interpretation of ST. His selection of corresponding lexical items, grammatical forms and stylistic equivalents is influenced by his empathy with author 
and message, or his lack of it. For after all, a translator is not a machine and his values, personality traits and emotional involvement may affect his rendition of ST.

Bearing in mind the concepts of dynamic equivalence and pragmatic principles of cooperation, the reception of TT is the ultimate assessment of quality. The feedback received from potential readers is the yardstick against which the success or failure of translation is measured. This hypothesis would entail, contrary to classical QA, that ST coordinates may not be the governing factor. A certain degree of transformation and manipulation should be allowed to cater for the TL discourse conventions.

Prior to launching a translation for public purposes (e.g. advertising, educational, instructional), market research via controlled and random groups of informants (or revision committees of TL stylistics) should be conducted to measure such pragmatic considerations as impact, image, acceptability, naturalness and fulfillment of expectation for both ST writer and TT recipients.

Along these lines, a follow-up to the present study would be a further investigation of the practicality of the proposed model with a greater variety of texts using different language pairs with various provinces and text types. Such studies should elicit informants' responses involving a number of monolingual and bilingual 'critics/ judges' whose task is to rate the TT version as per the proposed model.

\section{APPENDIX I}

English Source Text (ST I)

\section{METRO}

Your own sense of style is all your own. Brilliant. Colourful. Original. With loads of get up and go.

There's a car after your own heart. The new 1989 Metro. Sporty new models which look great - and don't hang around. A new range. With vivid new colours and trim. Full of fresh ideas. Luxurious. And wickedly stylish.

Get going in the new Metro GTa. Where else would you find 73PS performance, alloy wheels and looks like that - at such a price?

Or show what you're made of at the wheel of the new Metro Sport. It's got style. And a performance engine that says it's a lot more than just a pretty face.

Fancy something really special in the sports luxury department? With a sunroof, central locking, tinted glass and a lot more, the new Metro 1.3GS is just the ticket. And so is the price.

(Today's Cars, Austin Rover, 1989)

Arabic target Text (TT I)

$$
\begin{aligned}
& \text { إن التصميم المبتكر لمترو يجعل منها سيارة متألقة، جذابـة تناسب ذوقلك الخاص لما تتمتع به من } \\
& \text { قوة هائلة. }
\end{aligned}
$$

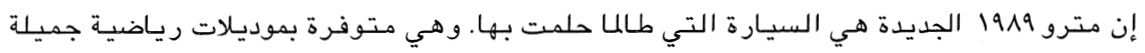

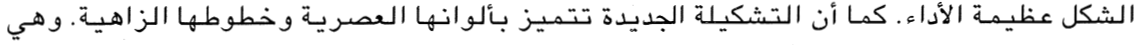

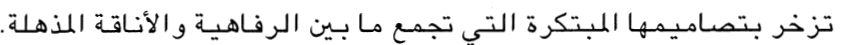

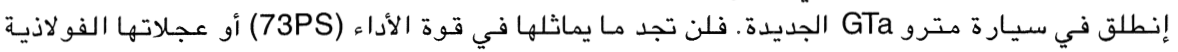

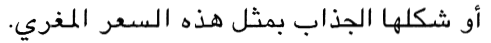

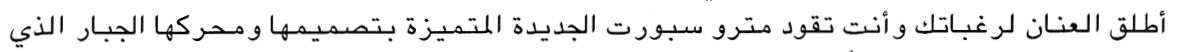

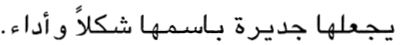

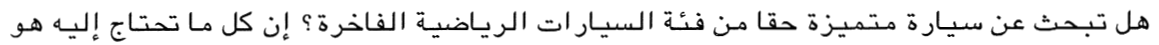

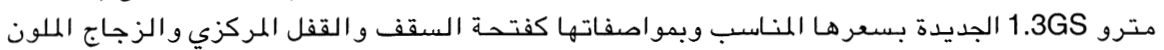

$$
\begin{aligned}
& \text { وغير ها الكثير. }
\end{aligned}
$$




\section{APPENDIX II}

English Source Text (ST II)

\section{METRO SPORT}

The new Metro Sport. Terrific looks. Loads of go. For a lot less than you think.

The Sport looks just what it is - a hot little hatchback that knows how to handle itself. With an aerodynamic tail spoiler; all-white sports wheel trims; and special graphics and paint treatment.

Under the bonnet is a 73 PS1.3 engine with a real sting in its tail. (Relax - it's also remarkably economical).

You won't have to put up with a spartan cockpit in return for sparkling performance. Just try those stylishly trimmed sports seats for size.

Now tune into the electric stereo radio/stereo cassette player. Four speakers, great sound. And a built-in security code theft deterrent.

There's a wealth of driving equipment too - including a tachometer of course.

Right up your street? Choose your Sport in one of five selected colours. And paint the town red. Source: Baker (1992: 71, 80).

Arabic target Text (TT I)

$$
\begin{aligned}
& \text { مترو سبورت }
\end{aligned}
$$

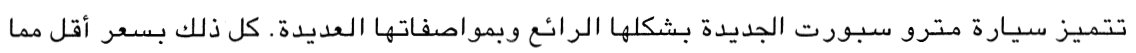

$$
\begin{aligned}
& \text { تتصور بكثير . تصني }
\end{aligned}
$$

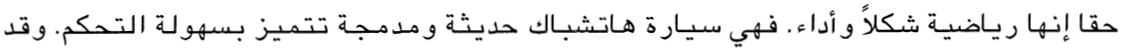

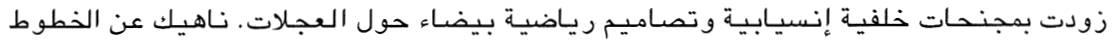

$$
\begin{aligned}
& \text { الخاصة و الطلاء المعالج بعنايه. } \\
& \text { وتحت غطائها المعدني يكمن محركها الجبار من نئة } 73 \text { PS1.3 (و لكن إطمئن، فهو اقتصـادي } \\
& \text { بصورة مذهلة). } \\
& \text { إن الأداء المتفوق لأهية يعني أن تقبل بمقصورة قيادة متواضعة. مـا عليك سوى أن تنعم نفسك بالمقاعد }
\end{aligned}
$$

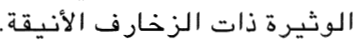

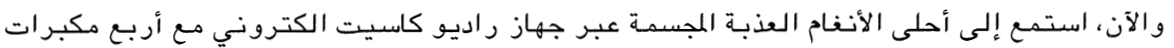

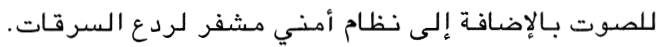

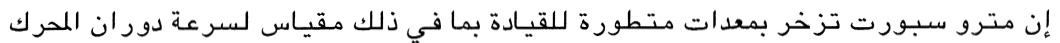

$$
\begin{aligned}
& \text { tachometer } \\
& \text { أليس هذا ما تصبو إليه؟ إذن إختر اللون الذي يروق لك من بـين خمسة ألوان منتقاة وانطلق إلى الم إنى } \\
& \text { عالم المرح الصـاخب. }
\end{aligned}
$$

\section{BIBLIOGRAPHY}

Azız, Y. “Style Shift in English Arabic Translation” (Personal Correspondence), 31 p.

BAKer, M. (1992), In Other Words, Routledge, London, 304 p.

BeLL, R. (1991), Translation and Translating, London, Longman, p 167.

Carrol, J. B. (1966), "An Experiment in Evaluating the Quality of Translations," in Mechanical Translation 9, pp. 55-66.

Hatim, B. and I. Mason (1990), Discourse and the Translator, Longman, London, 258 p.

Horton, David (May, 1998), "Translation Assessment: Notes on the Interlingual Transfer of an Advertising Text," in IRAL, Vol. XXXVI/ 2, pp. 95-119.

House, J. (1981), A Model for Translation Quality Assessment, Tübingen, Gunter Narr, 344 p.

ITI Conference 7 Proceedings (April, 1994), Quality-Assurance, Management and Control, Nottingham, U. K., 220 p.

Jackobson, R. (1959), “On linguistic Aspects of Translation,” in R. A. Brower (ed.), On Translation, Harvard, Harvard Univ. Press, pp. 232-9. 
Newmark, P. (1982), Approaches Translation, Oxford, Pergamon Press, 200 p.

— (1974), "Further Propositions On Translation: Part 2," in The Incorporated Linguist, 13:3, pp. 62-72.

NidA, E. (1964), Towards a Science of Translating, Leiden: E. J. Brill, pp. 155-159.

— and C. R. Taber (1969), The Theory and Practice of Translation, Leiden: Brill, 218 p.

Ogden, C. K. and I. A. Richards (1946), The Meaning of Meaning, 8th edition, London, Routledge, p. 229.

ReIss, K. (1971), “Die Bedeutung Von Texttyp und Textfunktion”, in Linguistica Antverpiensia 5, pp. 137-48.

WiLss, W. (1982), The Science of Translation, Tübingen: Gunter Narr, 292 p. 